\title{
Spermiogram and Morphological Characteristics in Testicular and Epididymal Spermatozoa of Large White Boar in Nigeria
}

\author{
Espermiograma y Características Morfológicas de los Espermatozoides en el Testículo y Epidídimo \\ del Verraco Grande Blanco en Nigeria \\ Oyeyemi Matthew Olugbenga \& Ubiogoro Oniovosa
}

OYEYEMI, M. O. \& UBIOGORO, O. Spermiogram and morphological characteristics in testicular and epididymal spermatozoa of large white boar in Nigeria. Int. J. Morphol., 23(3):235-239, 2005.

SUMMARY: Ten healthy male (boar) of large white pigs aged between 6.0 and 18.0 months, were used for this study. Spermiogram and morphological characteristics were studied in testes and in the different parts of the epididymis of the boar. The objective was to study the changes that occur in testes and epididymis during epididymal transit. Progressive motile spermatozoa were first observed in the testes (6-10\%) in the caput (20-30\%), corpus (40-50\%) and highest at the caudal epididymis (85\%). Cytoplasmic droplets were lost as the spermatozoa moved up the epididymis. The caput epididymis had a value of $20.05 \%$ of abnormal sperm cell, which is different significantly $(\mathrm{p}<0.5)$ from $15-80 \%$ of the caudal epididymis. The total abnormal sperm cells in corpus are also higher than in the caudal epididymis Percentage motility was $0.6 \pm 2.0 \%$ in the testis, which was lower $(\mathrm{P}<0.5)$ than in caput with $23.0 \pm 5.0 \%$. This motility increases from caput to caudal epididymis. The caput epididymis also had $0.20 \%$ of spermatozoa with small head, which differed significantly $(\mathrm{p}<0.05)$ from corpus $(0.05 \%)$ and the caudal $(0.00 \%)$.

The testicular and epididymal parameters were positively correlated (weight of testis and epididymis; weight of testis, scrotal circumference, testicular circumference, weight of epididymis and weight of testis $(\mathrm{p}<0.05)$, except the correlation values between testes and epididymis circumference (TEC) and other parameters $(\mathrm{p}<0.01)$

KEY WORDS: Spermiogram; Boar; Spermatozoa; Motility.

\section{INTRODUCTION}

Reproductive ability in the male comprises the production of semen containing normal spermatozoa (quality) in the adequate number (quantity), together with the desire and ability to mate. The epididymis is an extremely large convoluted structure, which is closely attached to the dorsal part of the lateral surface of the testicle (Setchell, 1977: Oyeyemi et al., 2000). Its functions include storage, maturation and absorption of sperm cells. Changes occurring in sperm during epididymal migration, have been correlated with the function, integrity of the testis and the epididymis (Rao, 1971). This has led to the classification of sperm defects into primary and secondary or major and minor sperm defects (Bloom, 1973) although Moss et al., (1988) classified these defects into primary, secondary and tertiary or miscellaneous.

Coordinated sexual behaviour and first ejaculation in the boar usually occur at 5 - 8 months of age that boars attain puberty. Fertility gradually increase and get to the peak when the boar reaches about 18 months of age (Leman \& Rodefer, 1976; Hurtgen, 1986) and a peak level of sperm production is maintained until a gradual decline sets in at about 5 years of age (Hurtgen). Spermatozoa are carried in a large amount of secreted fluid from the seminiferous epithelium and rete testis into the torturous efferent ducts or ductuli efferentes, usually, about 13 to 15 in number, located adjacent to the head of the epididymis and opening into the epididymal duct. In the epididymis, peristaltic activity of smooth muscle is largely responsible for sperm transport. In the boars, the epididymal content usually undergo continuous dilution from the caput to the cauda epididymis. The time required in the domestic animals for spermatozoon transport through the epididymis, is about 7 to 15 days. Spermatozoa in the tail of the epididymis are 2 to 10 more fertile than spermatozoa from caput, apparently due to abnormalities in locomotion of the sperm cells taken from the head of the epididymis (Larsen, 1986 and Crabo, 1986). 
Most of the work relating to morphological changes of spermatozoa during epididymal transit has been on cattle (Igboeli \& Foote, 1968: Amann \& Almquist, 1962: Cupps \& Briggs, 1965; Akusu et al., 1985), Red Sokoto goat (Awojobi \& Oyeyemi, 2000) and epididymal transit in West African buck (Oyeyemi et al., 2000). They have varying reports on the site of commencement of motility, stainability, morphology and position of the protoplasmic droplets.

This study was aimed at studying the changes in epididymal spermatozoa, thus contributing to the information on the epididymal transit of spermatozoa in boars.

\section{MATERIAL AND METHOD}

Sample collection: Testes from 10 sexually matured boars, aged between 6.0 and 18 months used for this study were collected from boars slaughtered at the pig unit of the Teaching and Research Farm, University of Ibadan and Bodija Abattoir, in Ibadan located about 2 kilometers from the University of Ibadan campus. The body weight, scrotal circumference, and scrotal length were measured for each animal prior to slaughter. The intrascrotal testes were placed in a well-insulated flask maintained at a warm condition $\left(37^{\circ} \mathrm{C}\right)$ immediately the animals were slaughtered. These were transferred to the laboratory.

Semen Collection and Microscopy: The right and left epididymis, were trimmed off the body of the testis and semen samples were collected from the three parts of the epididymis through a $1.0 \mathrm{~cm}$ incision made (with scalpel blade) on any of the locations (caput, corpus and cauda epididymis). Sperm cells were sucked into a Pasteur pipette from the caudal epididymis. The incisions of the caput and corpus epididymis flushed with $2-3$ drops of $2.9 \%$ buffered sodium citrate kept at body temperature. One half of the collected sperm sample was stained using Wells and Awa stains for morphological studies and Eosin and Negrosin stain for live-dead ratio. The second half was mixed with $0.5 \mathrm{ml}$ of $2.9 \%$ sodium citrate to study the progressive motility, while undiluted samples were used to study the mass activity. Except for mass activity, others were done under high power magnifications.

Statistical Analysis: Simple correlation coefficient was calculated for some testicular parameters. Paired comparisons were done using " $t$ " test where applicable. Analysis of variance was used where means was significantly differed; separation of means was also done using Duncan's multiple range test (Steel \& Torrie, 1980).

\section{RESULTS}

The summary of the percentage mean values of spermatozoa characteristics at different parts of the epididymis, regardless of age of the animals, is presented in Table I.

Testicular spermatozoa had a mass activity of zero (0). The mass activity for the caput, corpus and caudal epididymis were estimated as 1, 2, and 3, respectively. The progressive motility increase from caput, corpus and to the caudal epididymis. While only very slight vibratile motility was observed from the testes. Mean values of progressive motility for the different portions of the epididymis were estimated to be between, 20 - 30\% for caput, 40 - 50\% for the corpus, $80-90 \%$ for the caudal epididymis and $6-10 \%$ for the testes. Those values were significant $(\mathrm{p}<0.5)$ when compared Table 2 . Percentage live spermatozoa was generally high ranking between $40-60 \%$ in the testes, $70-80 \%$ in the caput and $80 \%$ and above in the corpus and caudal epididymis.

The caput epididymis has a significant higher mean value of $0.20 \%(\mathrm{p}<0.05)$ of abnormal spermatozoa with small head, compared to the corpus $0.05 \%$ and cauda $0.00 \%$. There were more of narrow head in caput and corpus than caudal epididymis, which differed significantly $(\mathrm{p}<0.05)$.

There were higher values $(\mathrm{p}<0.05)$ of proximal and distal cytoplasmic droplets in carput and corpus epididymis, when compared with the same values in the caudal epididymis.

Abnormalities in the tail to the spermatozoa in terms of coiled tail, curved tail are higher in the caput and corpus epididymis than in the caudal epididymis. The abnormalities in the middle piece (mid-piece) of the spermatozoa also follow the same trend (Table II).

The correlation coefficient for the testicular and epididymal parameters is presented in Table III. Except for testis and epididymal circumference, which was positively correlated $(\mathrm{p}<0.01)$, others testicular parameters showed positive correlation at each other at $\mathrm{p}<0.05$.

\section{DISCUSSION}

The observed morphological changes, which spermatozoa undergo in the caput epididymis, are lower when compared to the reports of Oyeyemi et al. (2000) 2 - 20\% in buck and Amann \& Almquist in the bull. 
Spermiogram and morphological characteristics in testicular and epididymal spermatozoa of large white boar in Nigeria. Int. J. Morphol., 23(3):235-239, 2005.

Table I. Mean percentage values of morphological characteristics of spermatozoa in the epididymis.

\begin{tabular}{llllllllllll}
\hline PE & TWE & SH & NH & LH & PCD & DCI & CT & CUT & TH & BM & TCA \\
Caput & 20 & $0.20^{\mathrm{a}}$ & $0.15^{\mathrm{a}}$ & $0.05^{\mathrm{b}}$ & $0.35^{\mathrm{a}}$ & $0.15^{\mathrm{a}}$ & 3.20 & 3.65 & 6.30 & $3.65^{\mathrm{a}}$ & 20.05 \\
Corpus & 20 & $0.05^{\mathrm{b}}$ & $0.15^{\mathrm{a}}$ & $0.15^{\mathrm{c}}$ & $0.40^{\mathrm{a}}$ & $0.15^{\mathrm{a}}$ & 2.90 & 3.15 & 5.85 & $2.85^{\mathrm{b}}$ & 18.00 \\
Cauda & 20 & $0.00^{\mathrm{c}}$ & $0.05^{\mathrm{b}}$ & $0.00^{\mathrm{a}}$ & $0.00^{\mathrm{b}}$ & $0.00^{\mathrm{b}}$ & 3.05 & 2.20 & 6.40 & $1.95^{\mathrm{c}}$ & $15.80 \mathrm{~s}$
\end{tabular}

Means with different letters on vertical column differ significantly $(\mathrm{p}<0.05)$.

$\begin{array}{lll}\text { PE: Parts of epididymis } & \text { LH: Large head } & \text { TH: Tailless head } \\ \text { TWE: Total number of epididymis } & \text { PCD: Proximal cytoplasmic droplet } & \text { BM: Bent mid-piece } \\ \text { SH: Small head } & \text { DCD: Distal cytoplasmic droplet } & \text { TCN: Total cell normal } \\ \text { NH: Narrow head } & \text { CT: Coiled tail } & \text { TCA: Total cell abnormal } \\ & \text { CUT: Curved tail } & \end{array}$

Table II. Mean percentage motility and livability in the testicles and epididymal spermatozoa.

\begin{tabular}{llll}
\hline & Percentage motility & Live/ dead ratio or Percentage live \\
\hline Testes & $0.6 \pm 2.0^{\mathrm{a}}$ & $1.5: 1$ & $60 \pm 10$ \\
Caput & $23 \pm 5.0^{\mathrm{b}}$ & $2.3: 1$ & $70 \pm 5$ \\
Corpus & $45 \pm 7.0^{\mathrm{c}}$ & $4.0: 1$ & $80 \pm 8$ \\
Caudal & $85 \pm 10.0^{\mathrm{d}}$ & $7.3: 1$ & $88 \pm 10$ \\
\hline
\end{tabular}

$\mathrm{a}, \mathrm{b}, \mathrm{c}, \mathrm{d}=$ value along the vertical column differently superscripted differ significantly $(\mathrm{p}<0.05)$.

Table III. Correlation Table for testicular and epididymal parameters.

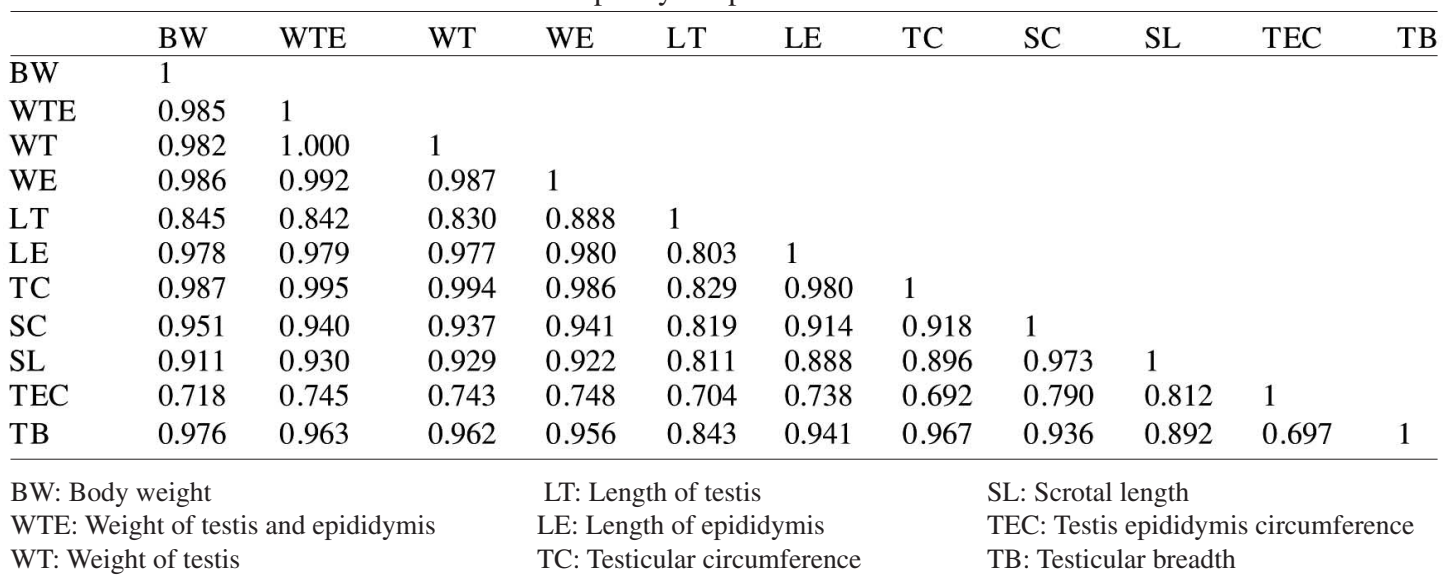

The value of abnormal acrosome or head of the spermatozoa in the caput $(0.40 \%)$ is higher $(\mathrm{p}<0.05)$ than corpus $(0.35 \%)$ and caudal epididymis $(0.05 \%)$. These values indicated that the abnormalities are from a defect in spermatogenesis, which is a primary abnormality. This is still lower than 5-10\% minimum allowed for primary abnormality (Zemjanis, 1977; Rozeboom, 2000).

The levels of immaturity of the sperm cells were indicated by cytoplasmic droplets, which showed a significant difference $(p<0.05)$ between the values of caudal epididymis and other two parts. The distal cytoplasmic droplets in the corpus and caput epididymis were higher $(\mathrm{p}<0.05)$ than the values in the caudal epididymis. The ability of the sperm to fertilize is required in the distal half of the body (corpus) of the epididymis. This may be the reason for the lower value observed for proximal cytoplasmic droplet. This agreed with the report of Cole \& Cupps, (1977) and Crabo.
The tail abnormalities showed that there was significant difference $(\mathrm{p}<0.05)$, in the incidence of curved tail in the caudal part when compared to other parts of epididymis. Other abnormalities (coiled tails, looped tails) in this study may partly reflect tertiary abnormalities that originated from epididymis (secondary) or spermatogenesis (primary). These findings are synonymous with the reports of Oyeyemi \& Akusu, (1998) and Lea et al., (1978).

The midpiece abnormalities indicated that bent midpiece was significantly higher $(\mathrm{p}<0.05)$ in the caput than in corpus and in turn higher $(\mathrm{p}<0.05)$ than values in the caudal epididymis. The same pattern was noticed in the curved midpiece but the values did not differ significantly.

The increase in values of tail and midpiece abnormalities may not be unconnected with high scrotal temperature of the animal prior to slaughter. This is in 
agreement with the reports of Oyeyemi et al. and Larsen, that testicles are affected in species of animals when testicles are not pendulous, also Cameron \& Blackshaw (1980) reported that boars kept outdoors have shown signs of testicular degeneration after exposure to extreme winter temperature.

There was a high correlation $(\mathrm{p}<0.05)$ between the testicular weight, body weight and other testicular parameters, like weight of testis and epididymis (WTE), length of testis (LT), testicular and scrotal circumference while there was positive $\mathrm{p}<0.01$ testes and epididymis circumference with other testicular parameters. This analysis was synonymous with the report of Willet \& Ohm (1957), Land \& Carr (1975) and Rozeboom, that testicular and epididymal parameters are positively correlated.

The higher percentage motility was recorded in caudal $(86 \pm 10 \%)$, which differed significantly $(\mathrm{p}<0.05)$, when compared to the motility values of corpus $(45 \pm 7 \%)$, caput $(23 \pm 5 \%)$ and testes $(06 \pm 2 \%)$. This indicates that more mature and motile spermatozoa capable of fertilization are found in the caudal epididymis of the boar, which is synonymous with reports on other breeds.

It is therefore concluded that boars raised under semi-intensive conditions can produce quality semen that can be used for either natural breeding or artificial insemination as long as the animals are not in anyway incubating any disease.

OYEYEMI, M. O. \& UBIOGORO, O. Espermiograma y características morfológicas de los espermatozoides en el testículo y epidídimo del verraco grande blanco en Nigeria. Int. J. Morphol., 23(3):235-239, 2005.

RESUMEN: Para la investigación se utilizaron 10 verracos de cerdos blancos de gran tamaño, con edades entre 6 y 18 meses. Se realizó el espermiograma y se observaron las características morfológicas, en los testículos y en las diferentes partes del epidídimo. El objetivo fue estudiar los cambios que ocurren en los espermatozoides a nivel de los testículos y del epidídimo durante el tránsito epididimal.

Los espermatozoides mótiles progresivos se observaron primero en testículos (6-10\%), en la cabeza (20-30\%), cuerpo (40-50\%) y en la cola de epidídimo (85\%). Pierden gotas citoplásmicas, en la medida en que los espermatozoides se trasladan ascendiendo hasta el epidídimo. La cabeza del epidídimo presenta un valor de 20,05\% de células anormales de espermatozoides, lo que es significativamente muy diferente ( $\mathrm{p}<0.5)$ de $15-80 \%$ en la cola del epidídimo. El total de espermatozoides anormales en el cuerpo del epidídimo, es también más alto que en la cola del epidídimo. El porcentaje de motilidad fue de $0,6 \pm 2,0 \%$ en el testículo, el cual era más bajo $(\mathrm{p}<0.5)$ que en la cabeza del epidídimo, con $23.050 \%$. Esta motilidad aumenta desde la cabeza a la cola del epidídimo. La cabeza del epidídimo también presenta $0,20 \%$ de espermatozoides con cabeza pequeña, lo que difiere significativamente $(\mathrm{p}<0.05)$ del cuerpo $(0,05 \%)$ y de la cola $(0,00 \%)$.

Los parámetros testicular y epididimal estaban positivamente correlacionados (peso del testículo y del epidídimo; peso del testículo, circunferencia escrotal, circunferencia testicular (peso del epidídimo y peso del testículo $(\mathrm{p}<0.05)$, excepto los valores de correlación entre testículos y circunferencia epididimaria $(\mathrm{TEC})$ y otros parámetros $(\mathrm{p}=0.01)$.

PALABRAS CLAVE: Espermiograma; Verraco; Espermatozoides; Motilidad.

\section{REFERENCES}

Akusu, M. O.; Akpokodje, J. U.; Ogwnegbu, S. O. \& Oke B. O. Differences in morphology of Bull spermatozoa from normal and pathological testis during epididymal transits. Nigerian. Vet. J., 14(2):30-33, 1985.

Amann. R. P. \& Almquist' J. O. Reproductive capacity of dairy bull vii; Morphology of epididymal sperm. J. of Dairy Science, 45:15-6, 1962.

Awojobi, H. A.; \& Oyeyemi, M. O. Morphological changes in epididymal spermatozoa of Red Sokoto (Maradi) Bucks. Nigerian J. animal production., 28 (2):207-10 2000.

Bloom, E. The ultrastructure of some characteristic sperm defects. Nord, Veterinary Medicine, 25:283, 1973.
Cameron, R. D. \& Blackshaw, W. The effect of elevated ambient temperature on spermatogenesis in the boar. $J$. Reprod. Fertility, 59:173-9, 1980.

Cole, H. H. \& Cupps P. T. Reproduction in domestic animals. 3. ed. Academic Press, New York. pp 65. 1977.

Crabo, B.G. Factors affecting spermatogenesis and boar fertility. In: Current therapy in Theriogenology. Diagnosis, Treatment and Prevention and Reproductive Diseases in Small and Large Animals. W. B. Saunders Company, 1986.

Cupps, P. T. \& Briggs, T. R. Changes in the epididymis associated with morphological changes in the spermatozoa J. Dairy Science, 48:124, 1965. 
Hurtgen, J. P. Mating systems and boar management. In Current Therapy and Theriogenology, 1986. pp 97880

Igboeli, G. \& Foote, R. H. Maturation changes in bull epididymal spermatozoa. J. Dairy Science, 51:495-7. 1968.

Land, R. B. \& Carr, W. R. Testes growth and plasma LH concentration following hemi castration and its relationship with female prolificacy in sheep. J. Reprod. Fert., 45:475. 1975.

Larsen, R. E. Semen collection from the Boar: In: Current Therapy in Theriogenology, W. B. Saunders Co., 1986. pp 969-72.

Lea, O. A.; Petrusz, P. \& French, F. S. Purification and localization of acidic epididymal glycoprotein (AEG); a sperm coating protein secreted by the rats' epididymis. Int. J. Androl. Suppl., 2:592-602, 1978.

Leman \& Rodefer. Boar Management Veterinary Rec. 98:457, 1976.

Moss, T. A.; Melrose, D. R. \& Reed, H.C.B. \& Vendeplasche, M. Spermatozoa, semen and artificial insemination. In: J. A. Laing (Ed) W. J. Brinley Morgan. Fertility and infertility in domestic animals, 4th ed., 1988.

Oyeyemi, M. O. \& Akusu, M. O. Short-term effect of hemiorchidectomy on testicular and ejaculate characteristics of West African Dwarf bucks. Small Ruminant Research, 31: 75-8, 1998.

Oyeyemi, M. O.; Ola-Davies, O. E.; Oke, A. O. \& Idehen, C. Morphological changes in sperm cells during epididymal transit in West African Dwarf Bucks. Tropical Veterinarian, 18: 207-12, 2000.

Rao, A. R. Changes in the morphology of sperm during their passage through the genital tract in bull with normal and impaired spermatogenesis. Ph.D. Thesis, Stockhol, pp 88, 1971.

Rozeboom, K. J. Evaluating Boar Semen Quality. In: Animal Science Facts, Extension Swine Husbandry. AN $500-8125.2000$.

Setchell, B. P. Male Reproductive Organs and Semen. In: Reproduction in Domestic Animals. 3rd. ed., 1977. pp 229-53.
Steel, R. G. D. \& Torrie, J. H. Principles and procedure of statistics. A Biometrics Approach. 2nd edition. McGraw Hill, New York, 1980.

Willet, E. L. \& Ohm, J. I. Measurement of testicular size and its relation to the production of spermatozoa by buck. J. Dairy Science 40:1559-69, 1957.

Zemjanis, R. Diagnostic and Therapeutic Techniques in Animal Reproduction. Williams and Wilkins Company, Baltimore, 1977.

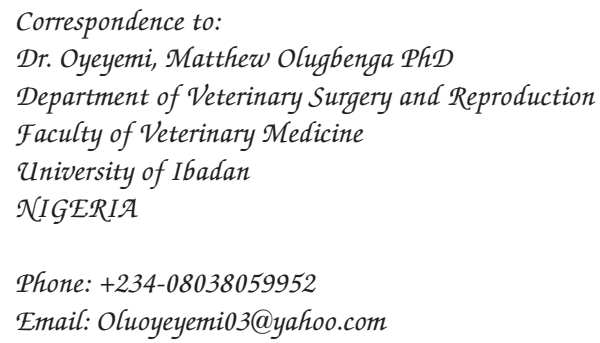

Received : 07-06-2005

Accepted: 20-08-2005 
